\title{
Transitivity Analysis of Colombian President Juan Manuel Santos' Nobel Peace Prize Lecture
}

\author{
Sthephanny Moncada Linares, Ph.D. Candidate \\ Xiamen University, China \\ sthephannyml@hotmail.com
}

Xin Zhi-Ying, Ph.D.

Xiamen University, China

xinzhiying@xmu.edu.cn

DOI: http://doi.org/10.36892/ijlls.v2i2.266

\begin{tabular}{|c|c|}
\hline $\begin{array}{l}\text { Received: } \\
\text { 81/04/2020 }\end{array}$ & $\begin{array}{c}\text { Abstract } \\
\text { The present document will offer an analysis of the Nobel Peace Prize }\end{array}$ \\
\hline $\begin{array}{l}\text { Acce } \\
20 / 05\end{array}$ & $\begin{array}{l}\text { acceptance lecture delivered by the former Colombian President, Juan } \\
\text { Manuel Santos, from the fundaments of the transitivity system provided } \\
\text { by the Systemic Functional Grammar theory. To attain this goal, a }\end{array}$ \\
\hline $\begin{array}{l}\text { Keywords: } \\
\text { Colombia peace } \\
\text { process; } \\
\text { Nobel Peace Prize; } \\
\text { Systemic Functional } \\
\text { Linguistics; } \\
\text { Transitivity system. }\end{array}$ & $\begin{array}{l}\text { Findings indicated that among the six transitivity process types, the } \\
\text { material processes (54\% - } 205 \text { realizations) dominate the speech } \\
\text { whereas the verbal, existential, and behavioral processes are relatively } \\
\text { low all together representing an overall occurrence of } 10 \%(41 \\
\text { realizations). This reveals that the speaker's main goal is to emphasize } \\
\text { the actions that led to consolidating the Colombian peace process, } \\
\text { placing him as the core actor of this achievement. Furthermore, by } \\
\text { employing a narrative thread that connects the past, the present, and } \\
\text { the future time, he can demonstrate to the world his capability as a } \\
\text { governor who deserves to be awarded the Nobel Prize. }\end{array}$ \\
\hline
\end{tabular}

\section{INTRODUCTION}

On December 2016 the former Colombian President, Juan Manuel Santos, delivered his Nobel Peace Prize lecture after being awarded "for his resolute efforts to bring the country's more than 50-year-long civil war to an end, a war that has cost the lives of at least 220.000 Colombians and displaced close to six million people" (Nobel Media AB, 2019).

Due to the transcendence of his proclaimed achievement for the Colombian people and the world and bearing in mind that "war" is a common experience and concern of mankind (Rahmanovic, 2012), it was found to be highly insightful and contributing to conduct a transitivity analysis on President's Santos speech. Based on Halliday's Systemic Functional Grammar theory (SFG), the present document aims at unveiling the hidden meanings encoded within the speaker's experience of the real world as perceived by him (Halliday, 1985; Halliday \& Matthiessen, 2004, Halliday, 1994), that is, his representation of the Colombian peace process achievement. In this sense, the question that guided this study is the following what are the communicative functions of the six transitivity process types in President's Santos Nobel lecture? This aim implied an interpretative content study of the linguistic choices employed by the speaker to reveal the role assigned to the participants involved in the actions, their relationship among each other, the emerging events and situations, etc. 
Previous transitivity studies conducted on different text types like literature, news, advertisement, school texts, among some others (Song, 2013; Ong'onda, 2016; Emilia, Moecharam, \& Syifa, 2017, Wang, Zhao, \& Jiang, 2017, etc.) have shown the significance of understanding the communicator's real purposes and intentions encoded behind the occurring language. During the last years, there has been an increasing and generalized interest in analyzing political speech, especially those concerning inaugurals, campaign, farewell address, etc. (Ewusi-Mensah \& Adjei, 2016; Zhang \& Zhao, 2017; Fengjie \& Yujie, 2018; Lemana \& Gatcho, 2019; Zheni, 2020). However, there seems to be a significant lack of research concerning the Nobel prize lectures, particularly the Noble Peace Prize, which according to Frye and Suchan (2017), is considered to be the premier award in the world that exalts the importance of the awardees' actions, and therefore, is "worthy of attention in understanding how highly engaged political actors use language and rhetorical appeals to advance peace" (p.57).

With the purpose to tackle the aforementioned need and thus, contribute to the theoretical-practical study of Nobel Price discourses from the field of SFG, the analysis of the former Colombian President is presented below. In this respect, this manuscript first provides a general overview of the supporting theory, then, it offers a brief description of the followed methodology, and finally, it displays the findings along with some concluding remarks.

\section{LITERATURE REVIEW}

From the perspective of the Systemic Functional Grammar (Halliday, 1994), language serves three core metafunctions that all together construe and represent the world of experiences (ideational metafunction), manage the flow of discourse to make into a coherent and unified text (textual metafunction), and enact individuals' interactions with the world (interpersonal metafunction). Inscribe within the ideational metafunction, there is the semantic notion of the transitivity system by which individuals embody in language their own experience of the outer and inner world (Halliday \& Matthiessen, 2004).

\section{Transitivity System}

As indicated by Halliday (1994), the transitivity system can construe and make sense of the experiences of the world through the realization of a set of six process types that are empowered by a process, that is, an experiential mode of a clause identified by a verb phrase, the participant(s) who are performing the process or being affected by it, and annex circumstantial elements.

The first and most recurrent process type is the one known as Material. It entails the notion "doing" and "happening" and involves the mandatory participation of an animate or inanimate actor to perform concrete actions, along with the reference of an optional goal that affects the process. The Mental process involves the portrayal of sensing experiences (perceptive, cognitive, desiderative, and emotive) by which a sensor, animate or inanimate, perceives, or feels a phenomenon. The Relational process, on the other hand, reflects states of "being" and "having," and are used to identify or assign an attribute to an entity through the engagement of a carrier. The Verbal process or act of "saying" implies the exchange of symbolic meanings enacted by a sayer(s); other participants also include a receiver(s), verbiage, and target. The realization of "existing" is carried out by the Existential process, it implies the presence of an entity or event labeled as existent. Finally, the Behavioral process represents physiological and psychological behaviors as a result of the individuals' inward thoughts; the participation of a behaver is required. 
Table 1. Occurrences of the Speech Acts in the Textbook

\begin{tabular}{cc}
\hline Process Type & $\begin{array}{c}\text { Example } \\
\text { (Participant in } \text { italics, Process in bold) }\end{array}$ \\
\hline Material & We will defend our nation \\
\hline Mental & They recognized their mistake \\
\hline Relational & Today's celebration is an important day \\
\hline Verbal & Sara told me the story behind her success \\
\hline Existential & There are more important things to care about \\
\hline Behavioral & They laughed on his face \\
\hline
\end{tabular}

\section{METHODOLOGY}

The corpus selected for the present analysis comprises President Santos' Noble Peace Prize lecture delivered in Oslo, Norway on 10 December 2016. To obtain reliable research results, the text was directly transcribed from the video-recorded version available at the official Nobel Prize website (https://www.nobelprize.org/prizes/peace/2016/santos/lecture/), originally addressed in Spanish. It should be noted that the English translated version provided as well by the Noble Prize site (https://www.nobelprize.org/prizes/peace/2016/santos/26112-juan-manuel-santos-nobel-lecture-20162/) was not considered for this study since it could drastically change the meanings inscribed within the speaker's discourse.

A mixed quantitative-qualitative methodical approach was applied to provide objectivity along with an in-depth understanding of the corpus, an interpretation guided by the Transitivity System framework offered by the Systemic Functional Grammar theory. In this regard, the steps considered to carry out the analysis included (1) identify the ranking clause complexes (meaning potentials) of the lecture; (2) locate and calculate the basis of the process types found in the clauses, following Halliday's selection criteria (1994); and (3) interpret the extracted data.

\section{RESULTS AND DISCUSSION}

From the transitivity analysis conducted to the President's Nobel lecture, it could be observed that it includes 158 clause complexes and 381 process types (see Table 2). These processes aim at construing and representing the President's experience of both the inner and the outer world (Halliday, 1994) of Colombia's social reality.

\begin{tabular}{|ccc|}
\hline Table 2. Frequency of Process & Types in the Nobel Lecture & \\
\hline Type of Process & Number of Processes & Percentage \\
\hline Material & 205 & $54 \%$ \\
\hline Relational & 83 & $22 \%$ \\
\hline Mental & 52 & $14 \%$ \\
\hline Verbal & 23 & $6 \%$ \\
\hline Existential & 13 & $3 \%$ \\
\hline Behavior & 5 & $1 \%$ \\
\hline Total & $\mathbf{3 8 1}$ & $\mathbf{1 0 0 \%}$ \\
\hline
\end{tabular}

The material processes have a higher occurrence accounting for $54 \%$ of the whole lecture. Relational processes come a distant second with $22 \%$ of frequency. Mental, verbal, and existential processes have an overall representation of 14\%, 6\%, and 3\%. Meanwhile, 
behavioral processes constitute only $1 \%$ of the speech. The result of the analysis of each of these process types is discussed below.

\section{Functions of Material Processes}

The material processes in the Nobel lecture take up the highest portion with 205 processes $(54 \%)$. This could imply that the speech mainly depicts physical actions that presumably intended to provide listeners with a general but still comprehensible background on the peace process of Colombia and how it was handled (see Table 3). Thus, from the speaker's deliberate choices of material processes, it can be presumed that the speech is divided into three major topics explained below.

Through processes such as murieron, asesinados, afectado, combatir, causó, defender, etc. (were killed, died, assassinated, affected, caused, to defend) President Santos depicts the negative side of a war that has lasted for half a century, and which has involved as main actors the Colombian citizens (men, women and children, us), the victims, FARC, and the Colombian Army.

Through verbs such as habíamos encendido, extinguirse, vencer, adelantamos, convenir, demostraron, logramos, etc. (we have ignited, extinguished, overcome, proceed, agree, showed to be, we did it) the speaker presents the efforts made and hardships faced during the negotiations with FARC. He placed as principal actors the second person plural pronoun "nosotros" (we -inclusive pronoun-) to refer to all Colombian citizens, along with the first person singular pronoun " $y o$ " (I/me), followed by FARC, the victims, and third parties (i.e., the international community and former Nobel Prize winners).

Processes like continuar, buscar, cambiar, no rendirse, transformar, despertarse, etc. (to continue, to look for, to change, not to give up, to transform, to wake up) seek to encourage the audience to share and actively participate in the pursuit of global peace, taking as reference the success achieved by Colombia. This call is accompanied by action verbs of the type encarcelar, consumirla, atacan, excluyen, se libran, etc. (imprison, consume it, attack, exclude, are fought) that aim at portraying the general panorama of the worldwide "culture of violence" and thus, stress the importance of being and living in peace with the Other. The actors responsible for accomplishing the aforementioned purpose are "nosotros" (we -inclusive pronoun-) referring to all individuals on earth and "ustedes" (you all), that is, the audience.

Table 3. Material Processes Analysis of the Noble Lecture

\begin{tabular}{|c|c|c|}
\hline Actor(s) & Processes & Goal \\
\hline $\begin{array}{l}\text { - My pocos - casi nadie } \\
\text { (very few - hardly } \\
\text { anybody), } \\
\text { - La paz (the peace-once-), } \\
\text { - Suppression of the Actor (- } \\
\text { 4l times-), } \\
\text { - el pueblo colombiano } \\
\text { (Colombian people) / los } \\
\text { colombianos (Colombians) } \\
\text { / Colombia (-2 times-) } \\
\text { - La guerra (the war -2 } \\
\text { times-), } \\
\text { - La guerra contra las drogas } \\
\text { (the fight against drug } \\
\text { trafficking), } \\
\text { - La forma cómo (the way } \\
\text { how), } \\
\text { - El mundo entero (the } \\
\text { whole world), } \\
\text { - Nosotros (we -24 times-), }\end{array}$ & $\begin{array}{l}\text { do) / nos hicieron (did to } \\
\text { acernos (made us) / hacer } \\
\text { / hice (I did) / hicimos } \\
\text { l) / haciendo (making) / he } \\
\text { (I have done) / hacemos } \\
\text { ), } \\
\text { (caused), } \\
\text { ninado (has ended) / } \\
\text { a / terminar (-2 times), } \\
\text { ron (they overcame), } \\
\text { cado (summoned) / } \\
\text { qué (I summoned), } \\
\text { nos encendido (we have } \\
\text { (), } \\
\text { adelantando (is } \\
\text { ding), }\end{array}$ & 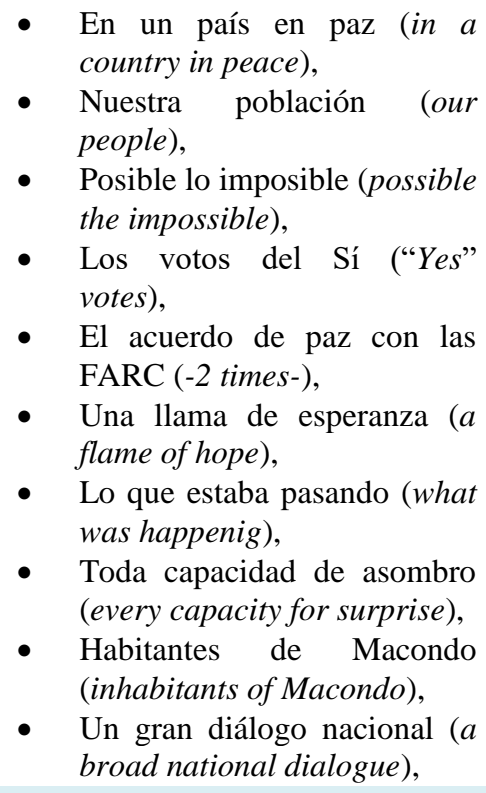 \\
\hline
\end{tabular}


- Llama (flame),

- Un pasaje de Cien Años de Soledad (a passage from One Hundred Year of Solitude),

- Dios (God),

- Yo (I-23 times-),

- Revés (setback),

- Quienes (those who),

- Esta noticia (this news),

- El Premio Nobel (the Nobel Prize),

- Un acuerdo (an agreement -8 times-),

- Ellos (they),

- El proceso de implementación (implementation process),

- Legalo (legacy),

- Alfred Nobel,

- Caminos de la paz (peace paths)

- El general Álvaro Valencia Tovar (the General Álvaro Valencia),

- Los historiadores (historians),

- 187 millones de personas (187 million people),

- La cuenta (the toll)

- Demasiados (too many people)

- La respuesta (the answer),

- Pesadilla (nightmare)

- Victimas (victims -4 times),

- Proceso de paz (the process of peace),

- El professor Ronald Heifetz (Professor Ronald Heifetz),

- Las FARC (a guerrilla group -4 times-),

- Habitantes (inhabitants),

- Hombres, mujeres y niños (men, women and children),

- Leyner Palacios,

- Hombres y mujeres (men and women -2 times-),

- Fuerzas Armadas de Colombia (Colombian army-once-),

- Comunidad internacional (international community),

- Mundo (world -2 times-),

- Un modelo de justicia transicional (a model of transitional justice),

- Valientes mujeres y hombres (brave women and men),
- Extinguirse (to extinguish),

- Mantuviera (kept)

- Votaron (voted -3 times-)

- Apoyar (support -2 times-)

- Se está ganando (is being won),

- Debo confesar (I have to confess),

- Llegó (arrived) / Llegar (to arrive -2 times-) / llegamos (got to),

- Impulsó (boosted),

- Vengo (I came),

- Lo logramos (we made it) / lograron (made) / lograr (to achieve-2 times-) / logramos (we were able to),

- Acoge (entails),

- Refrendado (endorsed),

- Comience (to start) / comenzó (it started) / comienza (it starts),

- Incorporarse (to implement),

- Nos reúne (gather us)

- Escribió (he wrote),

- Tratar (to try)

- Defender (to protect),

- Combatir (to fight -2 times-),

- Estaban cerrados (were closed)

- Vencer (to win),

- Aniquilar (to annihilate),

- Llevar (to take),

- Renunciar (to surrender),

- Compartiendo (sharing)/ comparto (I share) / compartir (to share),

- Me enseñó (taught me),

- Calculan (estimate),

- Murieron (died) / han muerto (have died),

- Creciendo (rising),

- Volando (flying),

- Construir (to build) / construyamos (we build)

- Recibo (I receive-2 times-) / han recibido (have received- 2 times-) / recibo, hemos recibido (we have received) / recibió (received),

- Trajo (brought),

- Devastadas (devastated)

- Asesinados (murdered),

- Ha puesto (they have given),

- Adelantamos (we carry out),

- Me gradué (I graduated)

- Me dio (it gave me) / darán (will give),

- Continuar (to continue),

- Pude (I could),

- Lanzado (launched),

- Cayó (landed),

- Habían buscado (had sought),

- Perdió (lost),
- La guerra contra las drogas (fighting against drugs trafficking),

- Un nuevo acuerdo (a new agreement -4 times-) / un acuerdo,

- $\quad$ No (no)

- Sí (yes),

- Esta noticia (this news),

- Nuestro destino (our destination),

- El puerto de la paz (the port of peace),

- La mayoría de las propuestas (the majority of the proposals),

- Una pregunta audaz (a haunting question),

- Un hemisferio (a hemisphere) I el mundo (the world -4 times-),

- La libertad y los derechos de los colombianos (the freedom and the rights of the Colombian people),

- La paz (the peace -3 times-),

- La guerra (the war-3 times-),

- Los grupos armados ilegales (the illegal armed groups),

- Diferencia (difference),

- Honor militar (military honour),

- Entre todos (we all),

- Dolor, miseria y atraso a nuestra nación (pain, misery and backwardness to our country),

- Víctimas y sus derechos (victims and their rights),

- Negociación (negotiations),

- Derechos humanos (human rights),

- Una paz estable y duradera ( $a$ stable and lasting peace),

- En la iglesia de su pueblo (on the church in his town),

- 32 familiares, incluidos sus padres y tres hermanos menores $(32$ relatives, including his parents and three younger brothers),

- Futuro (future),

- Pueblo colombiano (Colombian people),

- A mi familia: a mi esposa y mis hijos (for my family: for my wife and my children),

- $\quad$ El proceso de paz (the peace process),

- Pueblo noruego (to the people of Norway),

- Una agenda de negociación 
- Otros galardonados (other - He encontrado (have found), award-winners),

- Un llamado (a call),

- Flagelo (scourge),

- Campesino (peasant),

- Malala

- Pensamientos (thoughts),

- Palabras (words),

- Fin del conflict (the end of the conflict),

- Deforestación (deforestation),

- Ciudadanos (citizens),

- Las guerras y los conflictos (wars and conflicts),

- Diversidad (diversity),

- Aventura (adventure),

- Gabriel García Marquéz,

- Estirpes (lineage),

- Ustedes (you all),

- El sol de la paz (the sun of peace),

- Luz (light),

- La Unión Europea y el presidente Barack Obama (the European Union and the President Barack Obama).

- Reconciliarse (to reconcile),

- Enfrentarse (to confront),

- Negociaron (negotiated),

- Ofrecer (to offer),

- Alcanzar (to reach),

- Proteger (to protect),

- Respaldó (supported),

- Afectado (affected),

- Buscar (to seek),

- Esforzarse (to strive for),

- Encontrar (to find),

- $\quad$ No Rendirse (not to give up),

- Prepararse (to be ready),

- Asesorarse (to seek advice),

- Fijar (to set),

- Resuelva (to solve),

- Pretenda (that seeks to),

- Abarcar (to encompass),

- Tomar (to make) / toman (are made),

- Acercarme (reach out),

- Convenir (to agree),

- Obtener (to get),

- Sacrificar (to sacrifice),

- Celebramos (we celebrate),

- Avanzar (to move on),
- Demostraron (they demostrated),

- Recogimos (we gathered),

- Condujo (led to),

- Replantear (to stake out),

- Ha puesto (has given),

- Controlar (to control),

- Alimentar (to nurture) / se alimentan (are nurtured),

- Romper (to break),

- Contribuir (to contribute),

- Encarcelar (imprison),

- Siembra (who grows)

- Producirla (produce it),

- Consumirla (taking in),

- Se libran (waged),

- Cambiar (to change -4 Times-)

- Formando (to educate),

- Transformar (to transform),

- Crean (they create -2 Times-)

- Traerá (will bring),

- Reemplazar (to replace),

- Generada (caused by),

- Ser verterán (spilled),

- Se Premia (is awarded) /

- Se han realizado (have been execured),

- Encontrar (to find),

- Se cierran (are closed),

- Se ataca (are attacked),

- Se excluye (are excluded),

- Convivir (to coexist),

- Enriquece (enriches),

- Poblar (populate),

- Despertemos (let's awaken), realista y concreta (a realistic and concrete agenda),

- Los asuntos directamente relacionados con el conflicto (the issues directly related to the conflict),

- Todos los problemas de la nación (all the problems faced by the nation),

- Negociaciones con discreción y confidencialidad (negotiations with discretion and confidentiality),

- Decisiones difíciles (crucial decisions),

- El objetivo final de la paz (the final objective of the peace),

- Gobiernos de países vecinos (governments neighbouring countries),

- Un modelo de justicia transicional (a model of transitional justice),

- El máximo de justicia sin sacrificar la paz (the maximum of justice without sacrifing peace),

- El más prestigioso de los premios (the most prestigious of prizes),

- Un proceso a la medida de Colombia (a process specially designed for Colombia),

- Una sesión especial de la Asamblea General de las Naciones Unidas (a special session of the General Assembly for the United Nations),

- La guerra mundial contra las drogas (the world war on drugs -3 times-),

- La violencia y la corrupción en toda nuestra comunidad global (violence and corruption throughout our global community),

- Cualquier vínculo con el negocio de las drogas (any tie with the drug business),

- Una solución global (global solution),

- Campesino (peasant),

- Las iniciativas de Malala (initiatives of Malala),

- $\quad$ Las mentes (the minds),

- La realidad (the reality),

- Nuestras palabras (our words),

- Nuestras acciones (our actions),

- La cultura de violencia por 
- Cortar (to cut),

- Comenzaron (started),

- Alcanzar (to reach),

- Condenadas (condemned),

- Doy (I give),

- Ayudaron (helped),

- Brilla (shines),

- Ilumine (lights),

- Apoyar (Support). una cultura de paz y convivencia (the culture of violence with a culture of peace and coexistence),

- La cultura de la exclusión por una cultura de inclusión y tolerancia (the culture of exclusion into a culture of inclusión and tolerance),

- $\quad$ El planeta (the planet),

- Importantes dividendos ambientales (high environmental dividends),

- Los cultivos ilícitos por cultivos legales (the illicit crops with legal ones),

- Millones de barriles de petróleo a nuestros ríos y mares (millions of barrels of oil will no longer be spilled in our rivers and seas),

- Muchos esfuerzos positivos (many positive efforts),

- Las decisiones más cruciales (the most crucial decisions),

- El camino del perdón y la reconciliación (the path of forgiveness and reconciliation),

- Las fronteras a los inmigrantes (borders to immigrants),

- Las minorías (the minorities),

- Los diferentes (people deemed different),

- $\quad$ La diversidad (the diversity),

- Este planeta (this planet),

- La capacidad creadora para el bien, para la construcción de la paz (the creative capacity for goodness, for building peace),

- Humanidad (humanity),

- La raíz misma de los conflictos y de las guerras (the root of conflicts and war),

- Los esfuerzos (the efforts),

- La paz de Colombia mediante el diálogo (Colombia's peace via the dialogue),

- Un esfuerzo por la paz (peace efforts),

- $\mathrm{Al}$ mundo entero (the whole world),

- El crucial proceso de implementación (the crucial implementation process).

From the analyzed information concerning the material processes found in the President's lecture, it can be inferred that apart from presenting the negative side of the war, 
the efforts made to overcome it, and encourage listeners to live in peace, mostly, the speaker attempts to make the audience feel the power, decisiveness, and forcefulness of his administration to persuade them on his right to be awarded the Nobel Prize as a reward for accomplishing an extraordinary and almost impossible achievement. What is more, the deliberate choices of the key actors participating in the peace process, that is, the second person plural pronoun "nosotros" (we/us, directly and indirectly, mentioned 24 times) and the first person singular pronoun "yo" (I/me, directly and indirectly, mentioned 24 times), depict him as the prime "doer" of the peace agreement and therefore, the leader who "ended the war" in Colombia. The actor "we/us" in most of the lecture is anaphorically used to represent the President himself, and sometimes, the citizens of Colombia. Little reference is made to the "government opponent," FARC (mentioned 4 times), and the victims (mentioned 4 times), who undoubtedly played a paramount role in the "peace achievement."

According to Fetzer \& Bull (2012), by anchoring self-representation in political discourse the speaker can reflect his/her leadership qualities as a competent, responsible, and caring subject, who knows what he/she does and therefore, is in control of the situation. This predication is intrinsically connected and represented with verbs that denote material actions. Likewise, Wang (2010) states that material processes are suitable to prove the achievements of a government, just as President Santos reassured through his Nobel lecture.

\section{Functions of Relational Processes}

Although being less than that of material processes, the relational process is far higher than that of the other processes, holding a frequency of 83 realizations $(22 \%)$ by which the speaker plans to identify and describe the notion of peace and war, his political role, and the coming future (see Table 4).

In this sense, within the President's lecture, the dichotomy between peace and war stands out. Taking as reference the Colombian social reality, he attributes positive qualities to the concept of peace and the peace process by portraying them as "es un rayo de esperanza" (it is a ray of hope), "es una demostración de que lo que parece imposible se puede volver posible" (it is a proof that seems impossible can become possible), "es el propósito más noble de cualquier sociedad" (it is the noblest goal of any society), "es el verdadero premio" (it is the real prize), "es un lider" (he is a leader), etc. Likewise but to a lesser extent, he alludes to the idea of war and represents it as what it is and what should not be (negative relational processes), he indicates for example "la guerra no puede ser de ninguna manera un fin en sí misma" (war cannot be an end in itself), "es tan solo un medio, y un medio que siempre debemos tratar de evitar" (it is only a means, and a means that we should always try to avoid), "humanizar la guerra no es solo limitar su crueldad" (humanizing war is not only limiting its cruelty). By contrasting these two antagonistic notions, the speaker seeks to make the audience aware of the existence of a real conflict connected to the past (war) and that has evolved to the present day (peace).

Along with the aforementioned, it can be observed that the relational processes in the lecture assign to the speaker attributes corresponding to those of a political subject par excellence. Santos identifies himself as a democratic and dialogic leader, who, from his position as former Minister of Defense and President, has had to face the conflict both as a contender (past time) and negotiator (present time). "he sido líder en tiempos de guerrapara defender la libertad y los derechos de los colombianos-y he sido líder para hacer la paz" (I have been a leader in times of war - to defend the freedom and rights of Colombians and I have been a leader in making peace) are the mentions that best illustrate this sense of agency and legitimize him as an effective and decisive action taker. Although in terms of frequency there are only two explicit mentions regarding the President's institutional role, these become highly intensive devices that place him as the central "carrier" and therefore, "doer" in the consolidation of peace in Colombia. 
The change of panorama of the Colombian reality, which "lies under the speaker's actions," serves as an encouragement for him to feel fully entitled to share the positive outcomes of the peace agreement and thus, preach on how it can be replicated all over the world to guarantee a peaceful future. An example of this includes allusions such as "la clave es esforzarse, buscar, encontrar y no rendirse" (the key is to strive, search, find and not surrender), "tenemos autoridad para afirmar- el mundo no ha logrado controlar..." (we have authority to affirm- the world has not managed to control...), "tenemos que ser capaces de convivir" (we have to be able to live together), "este modelo será uno de los legados más grandes..." (this model will be one of the greatest legacies...), etc. The image of the speaker is projected in the form of revelation, being strategically reinforced when mentioning, for example, one of the social problems that almost every nation has to overcome "la urgente necesidad de replantear la Guerra mundial contral las drogras" (the urgent need to rethink world war against drugs).

His testimony and further call for global transformation take him to make extensive use of the inclusive ellipted pronoun "nosotros" (we/us) as it can be seen in the following extracts "somos el resultado..." (we are the result of), "somos un pueblo, una sola raza" (we are a people, an only race), "somos seres humanos" (we are human beings), "somos creyentes de Dios" (we are God believers), etc. The recurrent use of the plural personal pronoun "we" indicates that the speaker wants to summon the audience to take actions together, by hearing this, they could feel empathy and compromise towards his goal and ultimately, towards him.

Table 4. Relational Processes Analysis of the Noble Lecture

\begin{tabular}{|c|c|c|}
\hline $\begin{array}{c}\text { Carrier / Possessor / } \\
\text { Token }\end{array}$ & Processes & Carrier / Possessor / Token \\
\hline 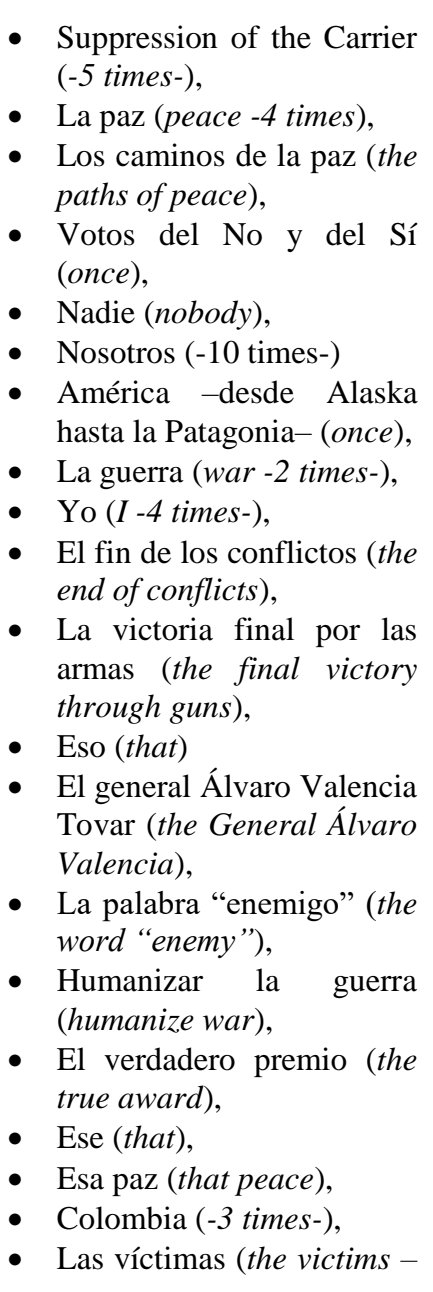 & 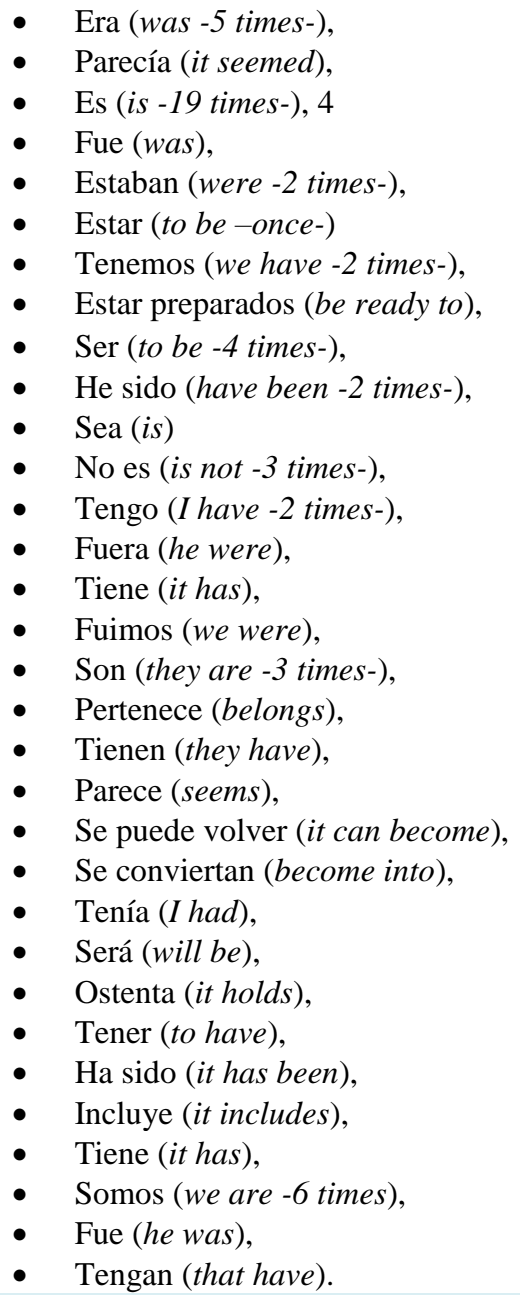 & 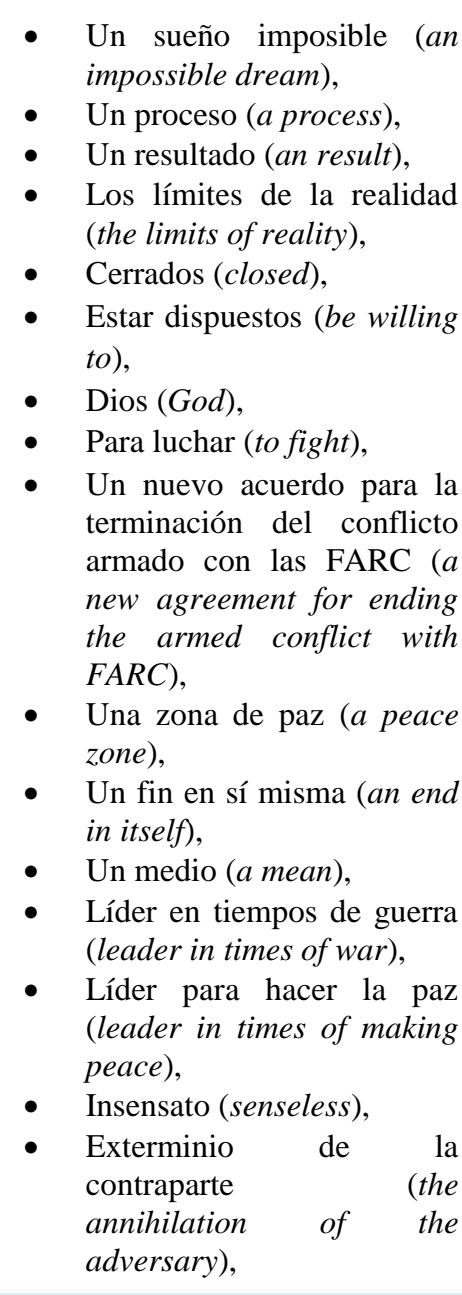 \\
\hline
\end{tabular}


once-),

- Leyner Palacios (once),

- Esta (this),

- Este premio (this award),

- La verdadera victoria del soldado y del policía (the true victory for the soldier and the pólice officer),

- Todos (all of them),

- El acuerdo de paz (the agreement of peace -5 times-),

- La clave (the key),

- Las negociaciones (the negotiations),

- El apoyo regional (the regional support),

- Todos los países de la región (all countries in the region),

- Búsqueda de la paz (the pursuit of happiness),

- Este modelo (this model),

- El proceso de paz en Colombia (the process of peace in Colombia -2 times-),

- País (country),

- Nuestro compromiso (our compromise),

- El acuerdo con las FARC (the agreement with FARC),

- El narcotráfico (drug trafficking),

- Todos (everybody),

- Ni el color de la piel, ni los credos religiosos, ni las ideologías políticas, ni las preferencias sexuales (not the colour of our skin; nor our religious beliefs; nor our political ideologies, nor our sexual preferences),

- Gabriel García Márquez,

- Las estirpes (the lineages),

- Leyner Palacios,

- La forma cómo (the way how),

- Cada una de ellas (each of them).
- Otra cosa que la derrota del espíritu humano (none other than the defeat of the human spirit),

- El honor (the honor),

- Comandante del Ejército de Colombia, historiador y humanista (Commander of the Colombian Army, a historian and humanist),

- Una connotación de lucha pasional y de odio (a sense of a passionate struggle and a connotation of hate),

- Solo limitar su crueldad (limits its cruelty),

- Jóvenes (young),

- La paz de Colombia (the peace of Colombia),

- Verdadero premio (the true award),

- De un presidente ni de un gobierno, sino de todo el pueblo colombiano (to a president or a government, but to all the Colombian people),

- El primero en el mundo (the first in the world),

- Una de estas víctimas (one of these victims),

- La gran paradoja (the great paradox),

- A los hombres y mujeres (to men and women),

- La paz (the peace),

- Razones (reasons),

- El más completo e integral de todos (the most complete and intergral of all),

- Un rayo de esperanza ( $a$ ray of hope),

- Una demostración (a demostration),

- Imposible (impossible),

- Posible (possible),

- Esforzarse, buscar, encontrar y no rendirse ( $t o$ strive, to seek, to find, and not to yield),

- Un circo mediático (a media circus),

- Profundas diferencias ideológicas (deep ideological differences),

- Indispensable (indispensable),

- Firmes aliados (firm allies),

- El propósito más noble de cualquier sociedad (the most noble purpose of any society),

- Uno de los más grandes 
legados del proceso de paz en Colombia (one of the greatest legacies of the peace process

Colombia),

- De Colombia (Colombia's).

- Una síntesis afortunada (a successful synthesis),

- El vergonzoso record (the shameful record),

- Con más minas y más víctimas de minas en el mundo (with more mines and victims in the world),

- $\quad$ Libre de minas para el año 2021 (free of mines by 2021),

- El país que más muertos y sacrificios ha puesto (the country that has paid the highest cost in deaths and sacrifices),

- Autoridad moral (moral authority),

- El compromiso de este grupo (the compromise of this group),

- Un problema (a problem),

- Sentido (sense),

- $\quad$ El resultado (the result),

- La síntesis y el resultado (the synthesis and result),

- Seres humanos (human beings),

- Creyentes (believers),

- Hijos de Dios (God's children),

- Parte de esa aventura mágica (part of this magical adventure),

- Apenas facetas de la rica diversidad del ser humano (simply facets of humans' diversity),

- Un solo pueblo y una sola raza, de todos los colores, de todas las creencias, de todas las preferencias (one people and one race; of every color, of every belief, of evey preference),

- Mi aliado en la búsqueda de la paz (my ally in the pursuit of peace),

- Una segunda oportunidad sobre la tierra (a second opportunity on earth),

- Un líder comunitario (a community leader),

- Igual o incluso más dañina (equal or even more harmful), 


\section{Functions of Mental Process}

Actions of sensing in the analyzed speech represent a section of 52 processes (14\%). Mental verbs are applied to represent processes of feeling and thinking (see Table 5).

With the purpose to express the inner experience of Colombians as result of the armed conflict and thus, arise in the audience the sense of the Other and its remembrance, the President conveys feelings of suffering encoded by verbs such as habiamos padecido, nos sentíamos, sufrir, etc. (we had suffered, we felt, to suffer). Along with this, he makes frequent use of the desiderative process "querer" (to want) in its different conjugation tenses to indicate the lack of peace and its urgent need for fulfillment. The sensors directly implied are the victims (mentioned 7 times), the Colombian army (mentioned twice), and the Colombian people in general (mentioned 5 times). There is few reference of the inclusive pronoun "nosotros" (we/us - mentioned once) and a non-existent indication of the pronoun "yo" (I/me), denoting that the speaker, indeed, does not perceive himself as a victim, he mainly seems to be affected by the negative result of the peace plebiscite as suggested by the verbs quedamos impactados, nos conmovió, no han sufrido (we were shocked, we were touched by, they have not suffered).

Additionally, the concurrent cognitive processes of the type saber, pensar, analizando, imaginar, aprender, recordaban, etc. (to know, to think, analyzing, to imagine, to learn, they remembered) intend to communicate to the audience the President's leadership experience and awareness of the armed conflict (they do not show opinions), and thus, build trustworthiness in his actions. The main sensor is depicted by the pronoun "nosotros" (we mentioned 8 times-) and the pronoun " $y o$ " (I/me -mentioned twice), both of them encompass the image of the President as a spokesperson of a collective, who shows to be fully conscious about what Colombians have experienced during the wartime based on what he has seen, thought and learned.

Overall, as Liping (2014) states, the use of mental processes makes the speech more convincing and therefore, persuasive, being this the ultimate goal of any politician.

Table 5. Mental Processes Analysis of the Noble Lecture

\begin{tabular}{|c|c|c|}
\hline Sensor(s) & Processes & Phenomenon \\
\hline $\begin{array}{l}\text { Colombianos } \\
\text { (Colombians -4 times-) / } \\
\text { Muchos (a lot of people } \\
\text {-once-) / casi nadie } \\
\text { (almost nobody-once-), } \\
\text { - } \quad \text { nosotros (we-11 times), } \\
\text { - } \quad \text { nadie (nobody-2 times), } \\
\text { - yo (I-8 times-), } \\
\text { - } \quad \text { barco (boat -once-), } \\
\text { - } \quad \text { sujeto tácito (implicit } \\
\text { subject-2 times-), } \\
\text { alguien (someone } \\
\text { once }), \\
\text { suppression of the senser } \\
\text { (2 times), } \\
\text { víctimas (victims -6 } \\
\text { times-), } \\
\text { usted (you-once-), } \\
\text { Fuerzas Armadas de } \\
\text { Colombia (Colombian } \\
\text { army -once-) / ellos } \\
\text { (they-once-). }\end{array}$ & 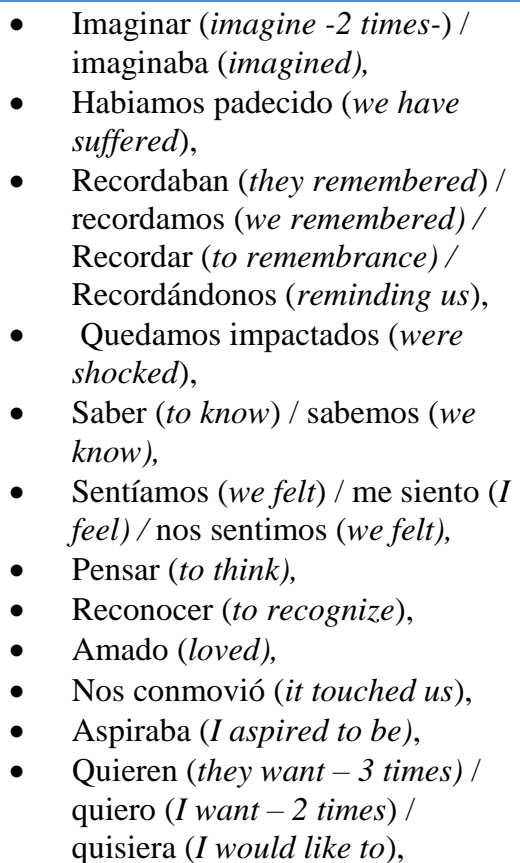 & $\begin{array}{l}\text { - Final de la guerra (the end of } \\
\text { the war), } \\
\text { un sueño imposible (an } \\
\text { impossible dream), } \\
\text { cómo era vivir en un país en } \\
\text { paz (how it was to live in a } \\
\text { peaceful country), } \\
\text { votos (votes), } \\
\text { - un resultado (a result), } \\
\text { - un pasaje de Cien Años de } \\
\text { Soledad (a passage of One } \\
\text { Hundred Year of Solitude), } \\
\text { límites de la realidad (the } \\
\text { limits of reality), } \\
\text { habitantes de Macondo } \\
\text { (inhabitants of Macondo), } \\
\text { la trascendencia de este } \\
\text { resultado adverso (the } \\
\text { significance of this adverse } \\
\text { result), } \\
\text { la deriva (the drift), } \\
\text { un mundo sin guerra (a world }\end{array}$ \\
\hline
\end{tabular}


- Comité del Nobel (Peace Nobel Commitee-once),

- Colombia (-once-).

- Leyner Palacios (name of a victim)

- Alfred Nobel (-once-),

- Colombia.
- Entendí (I understood) / Entendieron (they understood) / entendemos (we understand), comprendamos (understand),

- Analizando (analyzing),

- Apredimos (we learnt) / aprendiendo (learning) / aprendí (I leanrt) / hemos aprendido (we have learnt -2 times-),

- Han sido valorados (have been valued),

- Apreciar (to appreciate),

- Sufrir (to suffer).

- Los ha perdonado (has forgiven them)

- No han sufrido (have suffered)

- Se resisten (they resist to),

- Confió (trusted),

- $\quad$ Está disfrutando (is enjoying). with no war),

- $\quad$ el fin del conflicto (the end of the conflict),

- ardua experiencia (hard experience),

- adversaries (opponents),

- familia y seres queridos (family and loved ones),

- $\quad$ la pregunta (the question),

- han muerto demasiados (too many have died),

- $\quad$ premio Nobel (Nobel Prize),

- $\quad$ pesadilla (nightmare),

- negociación (negotiation),

- justicia (justice)

- la verdad (the truth),

- no más víctimas (no more victims)

- $\quad$ las víctimas (the victims),

- $\quad$ voluntad (willignes),

- la verdadera victoria (the true victory),

- al unirme a la línea de valientes e inspiradores hombres y mujeres (to join the line of brave and inspiring men and women),

- $\quad$ el proceso de paz (the peace process),

- formando mentes (educating minds),

- cambio climático (climate change),

- esfuerzos positivos (positive efforts)

- nuestro pueblo se llama el mundo. Y nuestra raza se llama humanidad (our people is called world. And our race is called humanity),

- De esta segunda oportunidad (of this second chance).

\section{Functions of Verbal Process}

With modes of expression and indication, verbal processes occur in 6\% (23) of the corpus analyzed. These realizations are employed to celebrate the beginning of peace in Colombia, the reception of the Nobel Prize, and to reiterate a call for global peace (see Table $6)$.

President Santos, as the leading "sayer" with a high frequency of self-announcement clauses (pronoun "I" repeated 13 times) in comparison to other actors, intends to make the audience fully aware of the end of the Colombian conflict. He presents this fact by making use of the verbal choices "decir" (to tell / to say) in its different conjugation forms, and "anunciar" (to tell), verbs that are directly targeted to the audience of the lecture since they need to be convinced of the credibility of his message for them to replicate it to the world, as expected by the speaker. References as the following ones illustrate the aforesaid "puedo anunciar a ustedes y al mundo" (I can announce to you and the world), "vengo a decirles a ustedes - y a través suyo a la comunidad internacional- que lo logramos" (I come to tell you - and through you to the international community - that we made it), "puedo decirles, por 
experiencia propia, que..." (I can tell you, from my own experience, that...). Only two of his statements do not address the audience as explicit receivers "qué bueno poder decir que el fin del conflicto..." (it is good to be able to say that the end of the conflict...) and "con este acuerdo podemos decir que América..." (through this agreement we can say that America...).

As the receptor of the Nobel Prize, the speaker also employs verbal processes to express gratitude and make recommendations to the audience. For instance, he mentions "ellos me preguntaban si yo aspiraba al premio, siempre les respondía que para mí el verdadero premio era la paz de Colombia" (they asked me if I aspired to the prize, I always answered that for me the real prize was peace of Colombia), "debo decir que me siento honrado..." (I must say that I am honored), "para agradecer muy especialmente al pueblo Noruego" (to highly thank the Norwegian people), "de reiterar hoy un llamado..." (to reiterate today a call...), "tenemos autoridad para afirmar..." (we have the authority to affirm...), etc. These allusions attempt to create close rapport with the audience, as they are the ones recognizing and awarding his efforts.

It is worth noting that scarce verbal remark is made concerning the active involvement of FARC as peacemakers. Their contribution to the peace in Colombia is only praised twice along with the whole lecture "quiero exaltar esa voluntad de abrazar, de alcanzar la paz" (I want to exalt that willingness to embrace peace, to reach peace) and " $y$ me refiero tanto a los negociadores del Gobierno como a los de las FARC" (and I mean both the negotiators of the Government and FARC). From this, it can be inferred that the opponents' agency is given less importance and is almost imperceptible for those listening to his speech.

The low presence of verbal processes in the President's lecture could be attributed to his preference of outlining the Colombian peace process through actions (mental processes) mainly executed by him, and from which he has been a central witness. In this sense, he does not quote others' to relate to their experiences and depict the event, this presumption is supported by Rashid (2016), who suggests that speakers primarily rely on verbal processes to benefit from others' points of views and opinions and therefore, represent reality based on them.

Table 6. Verbal Processes Analysis of the Noble Lecture

\begin{tabular}{|c|c|c|}
\hline Sayer & Processes & Addressee or Target \\
\hline $\begin{array}{l}\text { - Yo (I-13 times-) } \\
\text { - El Comité Noruego (The } \\
\text { Norwegian Committee), } \\
\text { - Nosotros (we-2 times-), } \\
\text { - Él (he), } \\
\text { - Ellos (they), } \\
\text { - Los expertos (the experts), } \\
\text { - Suppression of the Sayer } \\
\text { - Conce), } \\
\text { - Comité del Nobel (the } \\
\text { - Gommittee of the Nobel), } \\
\text { Gabriel García Márquez. }\end{array}$ & 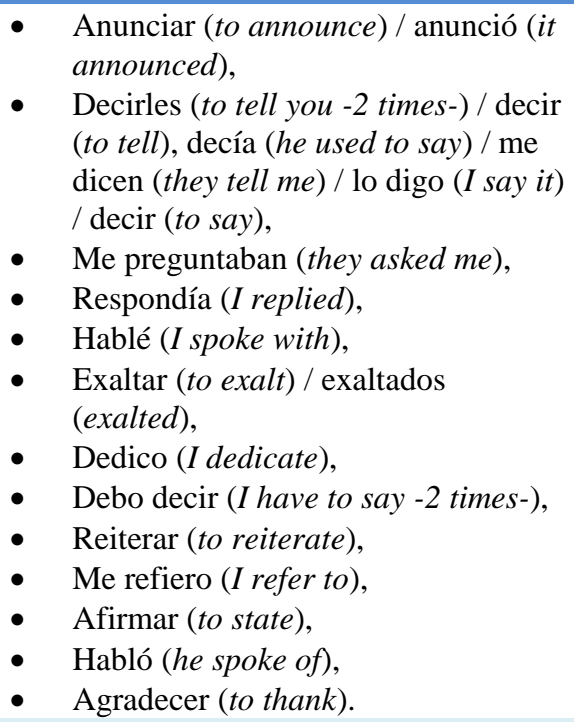 & $\begin{array}{l}\text { - A ustedes y al mundo } \\
\text { (to you and the the } \\
\text { world), } \\
\text { - A ustedes (to you), } \\
\text { - Yo (I), } \\
\text { - Las víctimas (the } \\
\text { victims), } \\
\text { - Los héroes de las } \\
\text { Fuerzas Armadas de } \\
\text { Colombia (the heroes } \\
\text { of the Armed Forces of } \\
\text { Colombia), } \\
\text { Pueblo } \\
\text { (Norwegian people). }\end{array}$ \\
\hline \multicolumn{3}{|c|}{ Verbiage } \\
\hline
\end{tabular}

- Que el pueblo colombiano está haciendo posible lo imposible (the Colombians are making possible the impossible),

- Una decisión igualmente sorprendente sobre la concesión del Premio Nobel de Paz (an equally surprising decision about the award of the Nobel Peace Prize).

- Que lo logramos (we made it), 
- Que América -desde Alaska hasta la Patagonia-es una zona de paz (the American continent - from Alaska to Patagonia - is a land in peace).

- Es mucho más difícil hacer la paz que hacer la guerra (it is much harder to make peace than to wage war),

- La palabra "enemigo" tiene una connotación de lucha pasional y de odio que no corresponde al honor militar (The word "enemy" gives a sense of passionate struggle and a connotation of hate, unfit for military honor).

- Si yo aspiraba al premio Nobel (I aspired to win the Nobel Prize),

- Para mí el verdadero premio era la paz de Colombia (for me, the actual prize was peace in Colombia),

- El proceso de paz en Colombia es el primero en el mundo que ha puesto en el centro de su solución a las víctimas y sus derechos (the Colombian peace process is the first in the world that has placed the victims and their rights at the center of the solution),

- De esta guerra (about this war),

- Esa voluntad de abrazar, de alcanzar la paz (that willigness to embrace peace, to reach peace),

- Nunca han dejado de proteger al pueblo colombiano (they have never stopped protecting the Colombian people),

- Cumplieron su trabajo con gran efectividad (did their job with great effectiveness),

- Me siento honrado y al mismo tiempo humilde (I feel honoured and humble),

- El proceso de paz en Colombia es una síntesis afortunada de lo que hemos aprendido de ellos (the peace process in Colombia is a fortunate synthesis of all what we have learned from them),

- Hoy un llamado (a call),

- La urgente necesidad de replantear la guerra mundial contra las drogas (the urgent need to rethink the world war on drugs),

- El mundo no ha logrado controlar este flagelo (the world has still been unable to control this scourge),

- El conflicto en Colombia...traerá importantes dividendos ambientales (The conflict in Colombia ... will yield high environmental dividends),

- Esfuerzos positivos (positive efforts),

- Una nueva y arrasadora utopía de la vida (a new and sweeping utopia of life),

- Por su carácter pacífico y su espíritu solidario (for your peaceful character and your spirit of solidarity).

\section{Functions of Existential Processes}

With a lower number of recurrence, 13 processes (3\%), the inclusion of existing and happening processes are important elements to analyze the Nobel Prize lecture. Verbs including "ser/esta" (to be) in its different realizations, "haber" (there is), "existent" (there exist), and "subsiste" (subsist) are used by the President to project the absence of peace and the existence of war, along with its participants (existents) (see Table 7), being the subject that summons his speech. The aforementioned is presented by allusions of the kind "pocos casi nadie- recordaban cómo era vivir en un país en paz" (few -almost nobody- remembered what it was like to live in a peaceful country), "dónde estaban los límites de la realidad" ("where were the limits of reality), “ipor qué no pueden estar libres de ella?” (why they cannot free from it), "cuántas muertes más serán necesarias" (how many death are necessary), "que no hayan nuevas víctimas" (no more victims), "los conflictos armados que subsisten" (the armed conflicts that subsist), "hay una guerra menos en el mundo" (there is one less war in the world).

The low frequency of existential processes in political speech, as stated by Zhang and Zhao (2017), could be a strategy of the speaker to avoid making monotonous and hard to draw attention on a given topic. Furthermore, it should be noted that the use of existential processes by the President, beyond emphasizing an objective perspective on the discussed topic as it would be expected from this type of processes (Jin, 1996), it entails a subjective and passionate point of view of the Colombian reality that might aim at touching the audience's emotional response and hence, connect with them. 
Table 7. Existential Processes Analysis of the Noble Lecture

\begin{tabular}{|c|c|c|}
\hline Existent(s) & Processes & Circumstance \\
\hline 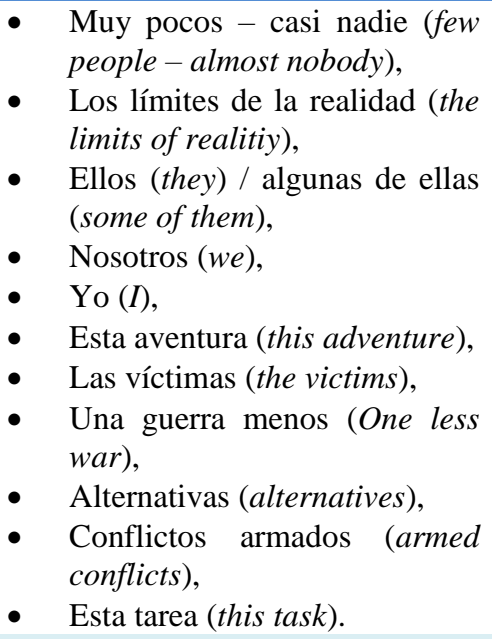 & $\begin{array}{l}\text { - } \quad \text { Era (it was), } \\
\text { - } \quad \text { No pueden estar } \\
\text { (cannot be), } \\
\text { - } \quad \text { Estar (to be -once-), } \\
\text { - } \quad \text { Están (are), } \\
\text { - } \quad \text { no hayan (there are } \\
\text { - } \quad \text { Hay (there is), } \\
\text { - } \quad \text { Existen (there are), } \\
\text { - } \quad \text { Que subsisten (that } \\
\text { subsist), } \\
\text { Hubiera sido (it would } \\
\text { have been). }\end{array}$ & $\begin{array}{l}\text { - } \quad \text { Vivir en un país en paz (to live } \\
\text { in a country in peace), } \\
\text { - } \quad \text { Lo imposible (the impossible), } \\
\text { - } \quad \text { Libres de ella (free of it), } \\
\text { - } \quad \text { Vivos aquí (here today -2 times-), } \\
\text { - } \quad \text { Tomar decisiones difíciles } \\
\text { - } \quad \text { Nueve difficult decisions), } \\
\text { - } \quad \text { En el mundo (in the world), } \\
\text { - } \quad \text { No violentas (non-violent), } \\
\text { - En el planeta (on the planet), } \\
\text { - Mucho más pesado (much } \\
\quad \text { heavier). }\end{array}$ \\
\hline
\end{tabular}

\section{Functions of Behavioral Processes}

With an overall representation of $1 \%$ (5 realizations), the behavioral processes are rarely applied in the President's lecture (see Table 8). Those few indications are encoded by the verbs "escuchar" (to listen to) and "ver" (to see), thus, the former one alludes to the speaker's sense of compromise towards the peace process and the war victims (their testimony can legitimize the negative consequences and effects of the armed conflict), whilst the later one intends to show to the audience that it was and it is compulsory to have a perspective shift if the goal is to overcome adversity. Some examples of this are "escuché sus desgarradoras historias" (I listened to their heartbreaking stories), "me dediqué a escuchar las inquietudes y sugerencias..." (I dedicated myself to listen to the concerns and suggestions...), "fue dejar de ver a los guerrilleros como enemigos" (it was stop seeing the guerilla as enemies), "es renunciar a ver en el contrario a otro ser humano" (is to give up on seeing on the other another human being).

The central behaver role is taken by the President himself, who attempts to prove that by being perceptive of the whole war and peace process scenario, he was acting as "politically" expected of a national leader as signaled by the process "to listen to." This portrays him as a skillful, compromised, and tactic agent, the inherent qualities of a favorable politician according to Latour (2003). On the other hand, the speaker places the behaver position on third agents to avoid providing explicit personal judgments to his adversaries as it can be observed in his use of the verb "to see."

Table 8. Behavioral Processes Analysis of the Noble Lecture

\begin{tabular}{|c|c|c|}
\hline Behaver(s) & Processes & Range \\
\hline $\begin{array}{l}\text { - } \quad \text { Yo }(I-2 \text { times }-) \\
\text { - Suppression of the Behaver } \\
\text { omitted (-2 times- }), \\
\text { Mis compatriotas (mi } \\
\text { compatriots }) \text {. }\end{array}$ & $\begin{array}{ll}\text { - } & \text { Escuché (listened to), } \\
\text { - } & \text { Escuchar (listen to), } \\
\text { - } & \text { Ver (to see } 2 \text { times-), } \\
\text { - } & \text { Que ven (who see). }\end{array}$ & $\begin{array}{l}\text { - Sus desgarradoras historias } \\
\text { (their heartbreaking stories), } \\
\text { Las inquietudes y sugerencias } \\
\text { de quienes votaron "No", de } \\
\text { quienes votaron "Sí", y } \\
\text { también de los que no votaron } \\
\text { (the concerns and } \\
\text { recommendations of those who } \\
\text { had voted "No," of those who } \\
\text { voted "Yes," and of the majority } \\
\text { who did not vote at all), } \\
\text { En el contrario a otro ser } \\
\text { humano (on the other another } \\
\text { human being), } \\
\text { A los guerrilleros como }\end{array}$ \\
\hline
\end{tabular}


enemigos (to the guerrillas as enemies),

- $\quad$ Por fin, terminar una pesadilla de más de medio siglo (finally, end a nightmare of more than half a century).

\section{CONCLUSION}

From the analysis conducted on President Santo's Nobel Peace Prize lecture, it can be concluded that material processes are the ones dominating his speech as these allow him to show the concrete and physical actions he carried out to achieve peace in Colombia. In comparison to the low frequency of verbal, existential, and behavioral processes, by displaying realizations of "doing" he portrays himself as an agent of actions rather than words and places himself as the central "doer". Moreover, the relational and mental processes with a higher presence in the lecture could suggest that the speaker construes and represents the world in terms of the dichotomy between peace and war and the promising future that awaits for the world if the latter one is achieved. This constitutes a testimonial narrative built on the past, the present, and future time by which the President can proudly announce to the world that his government's agenda has been fully accomplished, and therefore, he is in all his right to be exalted with the Nobel Prize.

Lastly, it should be highlighted that the present analysis provides a theoreticalpractical contribution to the literature on the field of discourse analysis and linguistics since it reveals how the notion of peace and its pursuit is construed via language by an influential actor such as the Colombian Nobel Prize winner, a research area still not sufficiently explored. Further research is recommended on the interpretation of the same study corpus by comparing it with its English translated version to verify whether the six transitivity process types still represent the same reality as the one portrayed in the original Spanish version.

\section{REFERENCES}

Emilia, E., Moecharam, N., \& Syifa, I. (2017). Gender in EFL classroom: Transitivity analysis in English textbook for Indonesian students. Indonesian Journal of Applied Linguistics, 7(1), 206-214. Retrieved from http://ejournal.upi.edu/index.php/IJAL/article/view/6877

Ewusi-Mensah, L., \& Adjei, A. (2016). Transitivity in Kufour's 2008 farewell speech to the Ghanaian parliament. British Journal of English Linguistics, 4(1), 36-49. Retrieved from http://www.eajournals.org/wp-content/uploads/Transitivity-in-Kufour---s-2008-FarewellSpeech-to-the-Ghanaian-Parliament.pdf

Fengjie, L., \& Yujie, Z. (2018). Transitivity analysis of American President Donald Trump's inaugural address. International Journal of Literature and Arts, 6(2), 28-34. Retrieved from http://www.sciencepublishinggroup.com/j/ijla

Fetzer, A., \& Bull, P. (2012). Doing leadership in political speech: semantic processes and pragmatic inferences. Discourse \& Society, 23(2), 127-144. Retrieved from http://citeseerx.ist.psu.edu/viewdoc/download?doi=10.1.1.901.1360\&rep=rep1\&type=pdf

Frye, J., \& Suchan, M. (2017). Nobel peace speech. Journal for Communication Studies, 10, 55-72. Retrieved from https://www.essachess.com/index.php/jcs/article/viewFile/363/406

Halliday, M. (1985). An introduction to functional grammar. London: Edward Arnold.

Halliday, M. (1994). An introduction to functional grammar. London: Edward Arnold. 
Halliday, M. \& Matthiessen, C. (2004). An introduction to functional grammar. London: Arnold.

Jin, C. (1996). Language arts and disciplines. Cambridge: Cambridge University Press.

Latour, B. (2003). What if we talked politics a little? Contemporary Political Theory, 2, 143-164. Retrieved from http://bruno-latour.fr/sites/default/files/downloads/83-POL-GB.pdf

Lemana, Y. \& Gatcho, Al. (2019). Unveiling the microstructure elements of President Rodrigo Duterte's interviews: A political discourse analysis. International Journal of Language and Literary Studies, 1(3), 100-111. https://doi.org/10.36892/ijlls.v2i1.112

Liping, C. (2014). Experiential metafunctional analysis of Winston S. Churchill's speech on Hitler's invasion of the U.S.S.R. English Language Teaching, 7(9), 132-136. Retrieved from https://files.eric.ed.gov/fulltext/EJ1075897.pdf

NobelPrize.org. (Wednesday 16 January 2019). Juan Manuel Santos - Nobel Lecture. Retrieved from https://www.nobelprize.org/prizes/peace/2016/santos/lecture/

Ong'onda, N. (2016). Transitivity analysis of newspaper headlines on terrorism attack in Kenya: A case study of Westgate Mall, Nairobi. International Journal of Humanities and Social Science, 6(9), 77-85. Retrieved http://www.ijhssnet.com/journals/Vol_6_No_9_September_2016/10.pdf

Rahmanovic, F. (2012). The theories of just war: Understanding warfare as a social tool through comparative analysis of Western, Chinese, and Islamic classical theories of war (Master of Arts dissertation, Hawai' $i$ at Mānoa, Hawai). Retrieved from https://scholarspace.manoa.hawaii.edu/bitstream/10125/101273/Rahmanovic_Faruk_r.pdf

Rashid, B. (2016). A linguistic analysis of Halliday's systemic-functional theory in political texts. International Conference on Humanities \& Social Sciences, (pp. 422-464). Thailand. Retrieved from https://hs.kku.ac.th/ichuso/2016/Panel_11.pdf

Song, Z. (2013). Transitivity analysis of A rose for Emily. Theory and Practice in Language Studies, 3(12), 2291-2295. Retrieved from http://www.academypublication.com/issues/past/tpls/vol03/12/20.pdf

Wang , H., Zhao , L., \& Jiang, J. (2017). A Transitivity analysis of on-line product descriptions-A case study of book product descriptions. ICBIM 2017 Proceedings of the International Conference on Business and Information Management, (pp. 73-77). Beijing.

Wang, J. (2010). A critical discourse analysis of Barack Obama's speeches. Journal of Language Teaching and Research, 1(3), 254-261. Retrieved from http://www.academypublication.com/issues/past/jltr/vol01/03/12.pdf

Zhang, Y., \& Zhao, M. (2017). A transitivity analysis of American President Donald J. Trump's inaugural address. International Journal of Liberal Arts and Social Science, 5(5), 31-43. Retrieved from https://www.ijlass.org/data/frontImages/gallery/Vol. 5 No. 5/5. 31-43.pdf

Zheni, T. (2020). Person deixis as biased political pronouns in George W. Bush's speeches on Iraqi War II. International Journal of Language and Literary Studies, 2(1), 155-171. https://doi.org/10.36892/ijlls.v2i1.112 


\section{$\underline{\text { AUTHORS' BIOS }}$}

Sthephanny Moncada Linares is currently a Ph.D. candidate at the Department of English language and Literature, School of Foreign Languages and Cultures, Xiamen University, China. She holds a Master of Arts in Applied Linguistics: Teaching Spanish as a Foreign Language (Pontificia Universidad Javeriana). During the school year 2012-2013, she served as a Spanish Assistant as a Foreign Language at the University of Wisconsin-La Crosse. Her main research interests include systemic functional linguistics, Computer Assisted Language Learning, and material design.

Dr. Xin Zhi-ying is a postdoctoral researcher from Sun Yat-sen University and holds the position of professor, supervisor of doctoral students, and Dean of the School of Foreign Languages and Cultures, Xiamen University, China. She specializes in systemic functional linguistics, discourse analysis, and language teaching. 